\title{
Estimations of dietary vitamin D requirements in black and white children
}

\author{
Kumaravel Rajakumar', Charity G. Moore², Jonathan Yabes ${ }^{3,4}$, Flora Olabopo', Mary Ann Haralam', Diane Comer ${ }^{3,4}$, \\ Michael F. Holick ${ }^{5}$ and Susan L. Greenspan ${ }^{4}$
}

BACKGROUND: The Institute of Medicine (IOM) dietary guidelines for vitamin $\mathrm{D}$ are based on limited pediatric data. Our objective was to estimate the dietary vitamin $D$ requirements for maintaining serum 25-hydroxyvitamin D [25(OH)D] concentrations at the various $1 \mathrm{OM}$-considered thresholds of vitamin D status $(12,16$, and $20 \mathrm{ng} / \mathrm{ml})$ during fall and winter in children.

METHODS: Ninety-six healthy 8- to 14-y-old Pittsburgh-area black and white children enrolled in a randomized, placebocontrolled trial of vitamin $D_{3}, 1,000$ IU daily for 6 mo with baseline and 2-mo follow-up assessments completed during October through April were studied. Vitamin D intake from diet and study supplement adjusted for adherence and serum 25(OH)D were measured.

RESULTS: The vitamin $D$ intakes needed to maintain serum $25(\mathrm{OH}) \mathrm{D}$ concentrations at 12,16 , and $20 \mathrm{ng} / \mathrm{ml}$ in $90 \%$ of the children were 581, 1,062, and $1543 \mathrm{IU} /$ day, respectively. The estimated vitamin D intakes needed to maintain serum $25(\mathrm{OH})$ D concentrations at $20 \mathrm{ng} / \mathrm{ml}$ in $97.5 \%$ of the children was 2,098 IU/day.

CONCLUSION: Our data suggest that the current vitamin D recommended dietary allowance (RDA) (600 IU/day) is insufficient to cover the skeletal health needs of at least $50 \%$ of black and white children.

V itamin D is an essential nutrient for bone health and calcium homeostasis. Rickets in children and osteomalacia in adults are disorders of poor mineralization of osteoid tissue and are the osteopathic consequence of severe and prolonged vitamin D deficiency (1). Maintaining optimal vitamin D status is critical for the prevention of rickets and the less severe consequences of hypovitaminosis D osteopathy. Sources of vitamin D include, mainly, vitamin D synthesized in the skin from casual sunlight exposure, diet, and dietary supplements (2-4). Skin color, season, and latitude of residence influence vitamin D photosynthesis (5-9). The Institute of Medicine (IOM) disregarded the contribution of "photosynthesized vitamin D" while calculating the dietary reference intakes (DRIs) for vitamin D because of the inherent risks of casual sunlight exposure, namely, photo-induced skin damage and skin cancer, and challenges posed by variations of human skin color for quantifying the safe duration of sunlight exposure needed for vitamin $\mathrm{D}$ synthesis (10).

The 2011 IOM vitamin D DRI guidelines were based on a risk assessment framework for indicators of bone health such as calcium absorption, bone mineral density, and risk of rickets and osteomalacia in healthy individuals (10). The DRI committee considered circulating concentration of total 25 -hydroxyvitamin $\mathrm{D}[25(\mathrm{OH}) \mathrm{D}]$ as a marker of vitamin D status and exposure, and defined concentrations $<12 \mathrm{ng} / \mathrm{ml}$ as deficient, and $\geq 20 \mathrm{ng} / \mathrm{ml}$ as sufficient, and deemed concentrations of 16 and $20 \mathrm{ng} / \mathrm{ml}$ as adequate to meet the skeletal health needs of 50 and $97.5 \%$ of the population, respectively (10). The estimated intake of vitamin D required to achieve a serum $25(\mathrm{OH}) \mathrm{D}$ concentration of $16 \mathrm{ng} / \mathrm{ml}$ in $50 \%$ and $20 \mathrm{ng} / \mathrm{ml}$ in $97.5 \%$ of $\geq 1$-y-old US children, respectively, was 400 and $600 \mathrm{IU} /$ day. These estimates, based on simulations of dose-response data gathered at higher latitudes during winter, were limited by insufficient pediatric data and lack of racially diverse sample of children, and remain to be refined. We utilized data from a randomized, double-blind, placebocontrolled vitamin $\mathrm{D}_{3}$ supplementation trial in black and white children and estimated the dietary vitamin $\mathrm{D}$ requirements for maintaining serum $25(\mathrm{OH}) \mathrm{D}$ concentrations at the various IOM-considered thresholds of vitamin D status $(12,16$, and $20 \mathrm{ng} / \mathrm{ml}$ ) during fall and winter.

\section{RESULTS}

We studied 96 black and white children with baseline and 2-mo follow-up assessments completed during October through April. The mean age of our study children was $11.4 \pm 1.9$ y. Fifty-two of the children were black and 51 of the children were randomized to the vitamin D supplemented group. Baseline characteristics between vitamin $\mathrm{D}$ and placebo group were similar (Table 1). Black children had higher BMI,

\footnotetext{
'Department of Pediatrics, University of Pittsburgh, Pittsburgh, Pennsylvania; ${ }^{2}$ Dickson Advanced Analytics Group, Carolinas HealthCare System, Charlotte, North Carolina; ${ }^{3}$ Center for Research on Health Care, University of Pittsburgh, Pittsburgh, Pennsylvania; ${ }^{4}$ Department of Medicine, University of Pittsburgh, Pittsburgh, Pennsylvania; ${ }^{5}$ Department of Medicine, Boston University School of Medicine, Boston, Massachusetts. Correspondence: Kumaravel Rajakumar (Kumaravel.Rajakumar@chp.edu) Received 12 October 2015; accepted 23 December 2015; advance online publication 30 March 2016. doi:10.1038/pr.2016.46
} 
Table 1. Baseline characteristics by intervention

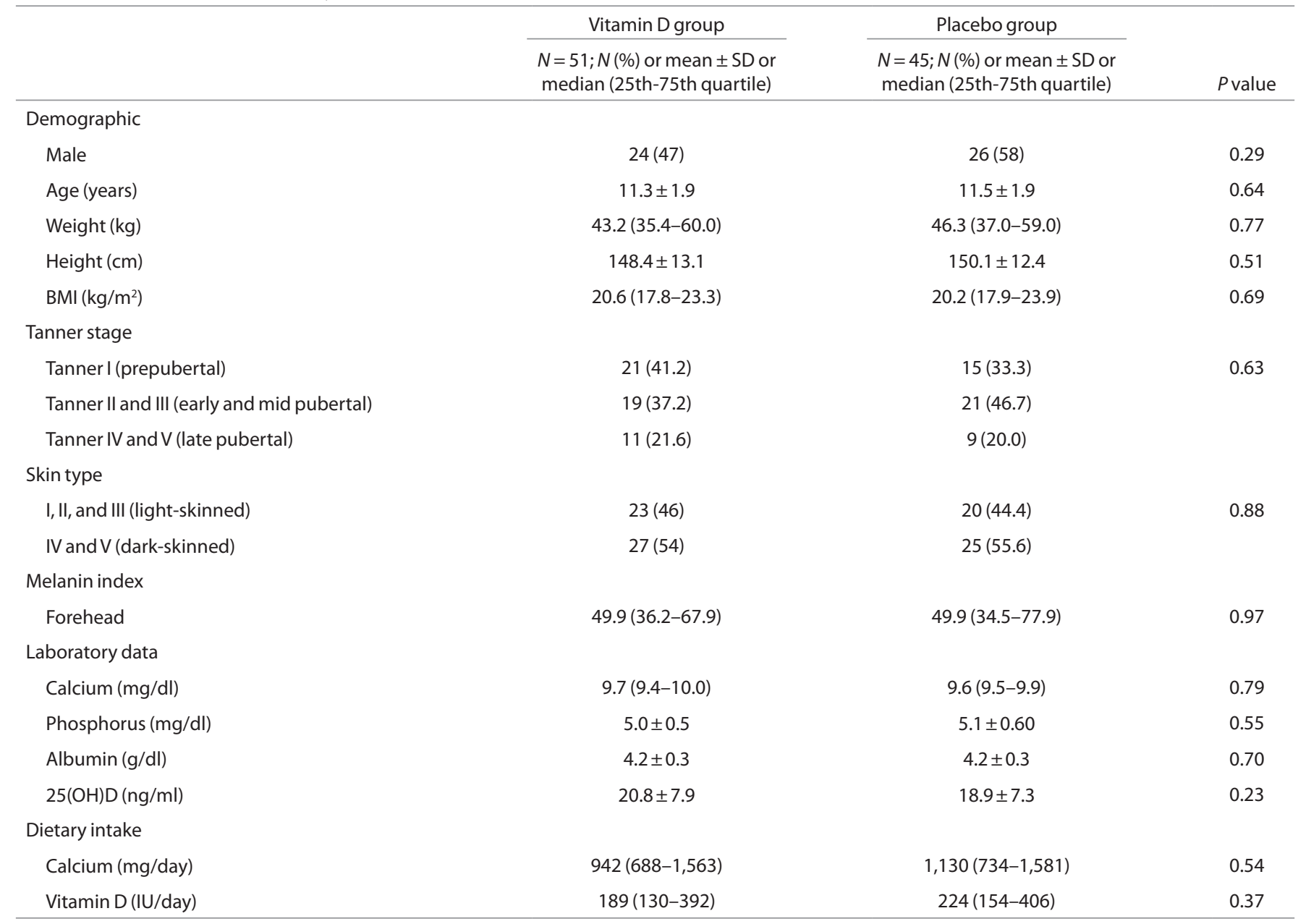

pubertal status, sunreactive skin type, and melanin index when compared to white children at baseline (Table 2). In addition, at baseline, black children had lower mean 25(OH)D concentrations and higher median serum calcium concentrations than white children (Table 2). Compliance rate by pill count was greater than $80 \%$ in the vitamin D and the placebo group and did not differ between the two groups (compliance median (25th, 75th percentile): vitamin D group $0.92(0.85,0.99)$ vs. placebo group $0.92(0.77,1), P=0.74)$. No child developed hypercalcemia during vitamin $\mathrm{D}$ supplementation.

\section{Effects of Vitamin D Supplementation}

Effects on mean 25(OH)D concentrations. Baseline 25(OH) $\mathrm{D}$ concentrations were not significantly different between the vitamin $\mathrm{D}$ and placebo group (Table 3 ). The 2-mo followup $25(\mathrm{OH}) \mathrm{D}$ concentrations were higher in children in the supplemented group than in children in the placebo group. The increase in $25(\mathrm{OH}) \mathrm{D}$ concentrations in the supplemented children and decrease in $25(\mathrm{OH}) \mathrm{D}$ concentrations in children in the placebo group were significant.

Effects on mean calcium, phosphorus, and albumin concentrations. Calcium, phosphorus, and albumin concentrations were not significantly different between the vitamin $\mathrm{D}$ and the placebo group at baseline and at the 2-mo follow-up visit (Table 3 ). The decreases in phosphorus and albumin concentrations in children in the placebo group were significant.

Correlations between change in 25(OH)D concentrations and baseline 25(OH)D concentrations. Lower baseline $25(\mathrm{OH})$ $\mathrm{D}$ concentrations were associated with a higher magnitude of change in $25(\mathrm{OH}) \mathrm{D}$ concentrations at the 2-mo follow-up overall $(r=-0.33, P=0.001)$, and in black children $(r=-0.49$, $P<0.001)$ but not in white children $(r=0.05, P=0.73)$. Also, the 2 mo changes in $25(\mathrm{OH}) \mathrm{D}$ concentrations in the vitamin $\mathrm{D}$ supplemented $(r=-0.43, P=0.002)$ and placebo $(r=-0.46$, $P=0.002)$ groups were inversely associated with baseline $25(\mathrm{OH}) \mathrm{D}$ concentrations.

\section{Relationship Between Total Vitamin D Intake and 25(OH)D Concentrations}

Total vitamin $\mathrm{D}$ intake derived from diet and study supplement (vitamin $\mathrm{D}_{3} 0$ or 1,000 IU daily) adjusted for adherence was positively associated with $25(\mathrm{OH}) \mathrm{D}$ concentrations during fall and winter (partial $r^{2}=0.245, P<0.0001$ ) as shown in Figure 1. The unadjusted slope of the relation between total 


\section{Articles | Rajakumar et al.}

Table 2. Baseline characteristics by race

\begin{tabular}{|c|c|c|c|c|}
\hline & All children & Black & White & $P$ value \\
\hline & $\begin{array}{c}N=96 ; N(\%) \text { or mean } \\
\pm \text { SD or median } \\
\text { (25th-75th quartile) }\end{array}$ & $\begin{array}{c}N=52 ; N(\%) \text { or mean } \\
\pm \text { SD or median } \\
\text { (25th-75th quartile) }\end{array}$ & $\begin{array}{c}N=44 ; N(\%) \text { or mean } \\
\pm \text { SD or median } \\
\text { (25th-75th quartile) }\end{array}$ & $\begin{array}{c}\text { Black vs. White } \\
\text { difference }\end{array}$ \\
\hline Male & $50(52)$ & $27(51.9)$ & $23(52.3)$ & 0.97 \\
\hline Age (years) & $11.4 \pm 1.9$ & $11.7 \pm 1.9$ & $11 \pm 1.8$ & 0.053 \\
\hline Height $(\mathrm{cm})$ & $149.2 \pm 12.8$ & $151.8 \pm 12.8$ & $146.2 \pm 12.1$ & 0.034 \\
\hline $\mathrm{BMI}\left(\mathrm{kg} / \mathrm{m}^{2}\right)$ & $20.4(17.8-23.6)$ & $21.8(18-27.1)$ & $19.7(17.0-22.1)$ & 0.019 \\
\hline \multicolumn{5}{|l|}{ Tanner stage } \\
\hline Tanner I (prepubertal) & $36(37.5)$ & $15(28.8)$ & $21(47.7)$ & 0.006 \\
\hline I, II, and III (light-skinned) & $43(45.3)$ & $6(11.8)$ & $37(84.1)$ & $<0.0001$ \\
\hline IV and V (dark-skinned) & $52(54.7)$ & $45(88.2)$ & $7(15.9)$ & \\
\hline \multicolumn{5}{|l|}{ Melanin index } \\
\hline Forehead & $49.9(35.2-73.1)$ & $73.1(59.0-82.0)$ & $35.2(33.7-38.6)$ & $<0.0001$ \\
\hline \multicolumn{5}{|l|}{ Laboratory data } \\
\hline Calcium (mg/dl) & $9.6(9.4-10.0)$ & $9.8(9.5-10.2)$ & $9.6(9.4-9.8)$ & 0.001 \\
\hline Phosphorus (mg/dl) & $5.0 \pm 0.5$ & $5.0 \pm 0.6$ & $5.1 \pm 0.5$ & 0.17 \\
\hline Albumin (g/dl) & $4.2 \pm 0.3$ & $4.3 \pm 0.3$ & $4.2 \pm 0.2$ & 0.064 \\
\hline $25(\mathrm{OH}) \mathrm{D}(\mathrm{ng} / \mathrm{ml})$ & $19.9 \pm 7.7$ & $17.0 \pm 7.4$ & $23.4 \pm 6.5$ & $<0.0001$ \\
\hline
\end{tabular}

vitamin D intake and 25(OH)D concentrations in black and white children was $0.94 \mathrm{ng} / \mathrm{ml}$ for each $100 \mathrm{IU} /$ day of vitamin D intake. Race did not modify the association between $25(\mathrm{OH})$ $\mathrm{D}$ concentrations and total dietary vitamin $\mathrm{D}$ intake $(P=0.50)$. Pubertal status was a significant predictor of $25(\mathrm{OH}) \mathrm{D}$ concentrations adjusted for total vitamin $\mathrm{D}$ intake $(P=0.005)$. Whereas race $(P=0.26)$ and BMI $(P=0.31)$ were not significant predictors of this association.

The slope of the relation between total vitamin $\mathrm{D}$ intake and $25(\mathrm{OH}) \mathrm{D}$ concentrations adjusted for race and pubertal status was $0.84 \mathrm{ng} / \mathrm{ml}$ for each $100 \mathrm{IU} /$ day of vitamin $\mathrm{D}$ intake $\left(R^{2}=0.36\right.$, $P<0.0001)$. Our estimated dietary vitamin $\mathrm{D}$ requirements for maintaining $25(\mathrm{OH}) \mathrm{D}$ concentrations at 12,16 , and $20 \mathrm{ng} / \mathrm{ml}$ in $50,90,95$, and $97.5 \%$ of our sample is shown in Table 4. Our data show that the vitamin $\mathrm{D}$ intakes needed to maintain serum $25(\mathrm{OH}) \mathrm{D}$ concentrations at 12,16 , and $20 \mathrm{ng} / \mathrm{ml}$ in $90 \%$ of the children were 581, 1,062, and 1,543 IU/day, respectively. The estimated vitamin D intakes needed to maintain serum 25(OH)D concentrations at $16 \mathrm{ng} / \mathrm{ml}$ in $50 \%$ of the children was $10.6 \mathrm{IU} /$ day and at $20 \mathrm{ng} / \mathrm{ml}$ in $97.5 \%$ of the children was 2,098 IU/day.

\section{DISCUSSION}

Our results indicate that the current recommended dietary allowance (RDA) for vitamin D may be inadequate in children residing in higher latitudes during winter. The IOM has suggested that maintaining $25(\mathrm{OH}) \mathrm{D}$ concentrations $\geq 20 \mathrm{ng} /$ $\mathrm{ml}$ as sufficient for optimal skeletal health in children and an intake of $600 \mathrm{IU}$ of vitamin D/day as the RDA for maintaining $25(\mathrm{OH}) \mathrm{D}$ concentrations at $20 \mathrm{ng} / \mathrm{ml}$ in $97.5 \%$ of children $\geq 1$ $\mathrm{y}$ of age (10). According to our findings, the current vitamin D RDA (600 IU/day) is insufficient to cover the skeletal health needs of at least $50 \%$ of black and white children.

The IOM vitamin D DRI committee had deemed $25(\mathrm{OH})$ D concentrations of $16 \mathrm{ng} / \mathrm{ml}$ as the median value for maintaining optimal skeletal health-concentration above which will be adequate for $50 \%$ of the population and concentration below which will be inadequate for $50 \%$ of the population (10). The committee set 12 and $20 \mathrm{ng} / \mathrm{ml}$ as the lower and upper limits of $25(\mathrm{OH}) \mathrm{D}$ requirements for meeting the skeletal health needs, with the presumption that $25(\mathrm{OH}) \mathrm{D}$ concentrations of $20 \mathrm{ng} / \mathrm{ml}$ would be sufficient to cover the needs of $97.5 \%$ of the 
Table 3. Laboratory data in vitamin $\mathrm{D}$ and Placebo groups before and after intervention

\begin{tabular}{|c|c|c|c|}
\hline & $\begin{array}{l}\text { Vitamin D } \\
\text { group } \\
(N=51) ; \\
\text { mean } \pm \text { SD }\end{array}$ & $\begin{array}{c}\text { Placebo } \\
\text { group } \\
(N=45) ; \\
\text { mean } \pm \text { SD }\end{array}$ & $\begin{array}{l}\text { Vitamin } \\
\text { D vs. } \\
\text { placebo, } \\
P \text { value }\end{array}$ \\
\hline \multicolumn{4}{|l|}{$25(\mathrm{OH}) \mathrm{D}(\mathrm{ng} / \mathrm{ml})$} \\
\hline Baseline & $20.8 \pm 7.9$ & $18.9 \pm 7.3$ & 0.23 \\
\hline Follow-up & $26.1 \pm 8.3$ & $17.1 \pm 7.0$ & $*<0.0001$ \\
\hline Within group change $P$ value & $<0.0001$ & 0.041 & \\
\hline \multicolumn{4}{|l|}{ Calcium (mg/dl) } \\
\hline Baseline & $9.7 \pm 0.4$ & $9.7 \pm 0.4$ & 0.70 \\
\hline Follow-up & $9.6 \pm 0.4$ & $9.6 \pm 0.3$ & ${ }^{*} 0.86$ \\
\hline Within group change $P$ value & 0.22 & 0.30 & \\
\hline \multicolumn{4}{|l|}{ Phosphorus (mg/dl) } \\
\hline Baseline & $5.0 \pm 0.5$ & $5.1 \pm 0.6$ & 0.55 \\
\hline Follow-up & $5.0 \pm 0.6$ & $4.9 \pm 0.6$ & ${ }^{*} 0.93$ \\
\hline Within group change $P$ value & 0.12 & 0.039 & \\
\hline \multicolumn{4}{|l|}{ Albumin (g/dl) } \\
\hline Baseline & $4.2 \pm 0.3$ & $4.2 \pm 0.3$ & 0.70 \\
\hline Follow-up & $4.2 \pm 0.3$ & $4.1 \pm 0.3$ & $* 0.43$ \\
\hline Within group change $P$ value & 0.27 & 0.034 & \\
\hline
\end{tabular}

population and $<12 \mathrm{ng} / \mathrm{ml}$ would be associated with vitamin $\mathrm{D}$ deficiency (10). The committee examined dose-response data from nine vitamin $\mathrm{D}$ intervention studies conducted during winter (minimal UV-B exposure) in 6- to $>60$-y-old individuals living in higher latitudes in northern Europe $\left(>49.5^{\circ} \mathrm{N}\right)$ and Antarctica $\left(78^{\circ} \mathrm{S}\right)$ and formulated a regression equation for estimating the response of $25(\mathrm{OH}) \mathrm{D}$ concentrations to total vitamin D intake (10). The IOM committee estimated vitamin D intake required to achieve a $25(\mathrm{OH}) \mathrm{D}$ concentration of $16 \mathrm{ng} / \mathrm{ml}$ in $50 \%$ of the population (estimated average requirement (EAR)) and $20 \mathrm{ng} / \mathrm{ml}$ in $97.5 \%$ of the population (RDA) were 400 and $600 \mathrm{IU} /$ day, respectively (10). Whereas, in our study, the EAR was $10.6 \mathrm{IU} /$ day and RDA was 2,098 IU/day. Our considerably lower EAR can be explained by likely the contributions of summertime sun exposure to serum $25(\mathrm{OH})$ $\mathrm{D}$ concentrations, as our study was conducted at a lower latitude $\left(40.4^{\circ} \mathrm{N}\right.$ and $\left.40.8^{\circ} \mathrm{N}\right)$ than the studies considered by IOM. The differences in the estimates can be attributed to the differences in the regression models and cohort characteristics. The IOM estimates were based on a curvilinear fit model derived using pooled data from 6 - to $>60$-y-old individuals, whereas our estimates were based on a linear regression model derived using data from a single site study of 8- to 14 -y-old black and white children, and half of our sample comprised of black children.

In this study, supplementation with vitamin $\mathrm{D}_{3}$ 1,000 IU daily for 2 mo during October through April was safe and effective. Mean 25(OH)D concentrations increased significantly in

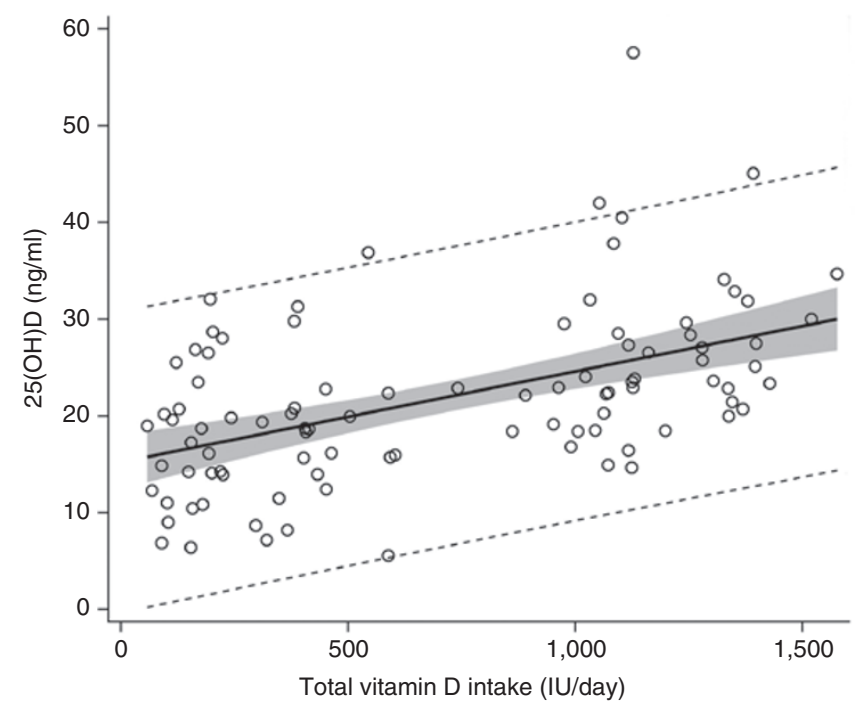

Figure 1. Relationship between serum $25(\mathrm{OH}) \mathrm{D}$ concentrations and total vitamin $D$ (diet + supplement $\times$ adherence) intake. The prediction line of this association is shown in bold. The shaded area encompassing the prediction line depicts the $95 \%$ confidence limits of the prediction line. The interrupted lines depict the $95 \%$ prediction confidence intervals.

the supplemented children and decreased significantly in the placebo group at $2 \mathrm{mo}$. The decrease in $25(\mathrm{OH}) \mathrm{D}$ concentrations in the placebo group reflect the influence of season on vitamin D status of children living in higher latitudes during fall and winter, and validate that our assessments were done during periods of minimal UV-B light exposure. The decrease in phosphorus and albumin at 2 mo in the placebo group was not clinically relevant. The magnitude of change in $25(\mathrm{OH})$ $\mathrm{D}$ concentrations at the 2-mo follow-up was inversely associated with baseline $25(\mathrm{OH}) \mathrm{D}$ concentrations in black but not in white children mainly because black children had significantly lower basal 25(OH)D concentrations than white children $(11,12)$.

In this study, pubertal status was a significant predictor of $25(\mathrm{OH}) \mathrm{D}$ concentrations. This finding is consistent with our previous report examining the predictors of $25(\mathrm{OH}) \mathrm{D}$ concentrations in 8- to 18-y-old black and white children (13). We speculate that this is primarily due to the fact that adolescent children have higher rates of vitamin D deficiency and lower intakes of dietary vitamin $\mathrm{D}$ when compared to preadolescent children (14).

Data regarding estimations of dietary requirements of vitamin D in children are limited. Cashman et al. (15) have reported a higher slope for the relation between vitamin $\mathrm{D}$ intake and $25(\mathrm{OH}) \mathrm{D}$ concentration $(2.43 \mathrm{ng} / \mathrm{ml}$ per $100 \mathrm{IU}$ of vitamin $\mathrm{D}_{3}$ ) during winter in 144 white, healthy adolescent Finnish (latitude: $55^{\circ} \mathrm{N}$ ) and Danish (latitude $60^{\circ} \mathrm{N}$ ) girls, and their estimated EAR and RDA were 200 and 744 IU/day, respectively. Stratified dosing (placebo or 200 or 400 IU/day) yielding a tighter and a well-correlated dose-response curve, a sample comprising of only Caucasian adolescent girls, higher basal $25(\mathrm{OH}) \mathrm{D}$ concentration $(22.6 \pm 5.6 \mathrm{ng} / \mathrm{ml})$, and lack of influence of basal $25(\mathrm{OH}) \mathrm{D}$ on the responsive changes in 


\section{Articles | Rajakumare tal.}

Table 4. Estimated dietary vitamin D requirement percentiles (IU/day) ${ }^{\mathrm{a}}$

\begin{tabular}{lcccc}
\hline $25(\mathrm{OH})$ D cutoff & 50 th & 90 th & 95 th & $97.5^{\text {th }}$ \\
\hline$\geq 12 \mathrm{ng} / \mathrm{ml}$ & $-\mathrm{-b}^{\mathrm{b}}$ & $581(340,785)$ & $877(635,1,151)$ & $1,137(856,1,493)$ \\
$\geq 16 \mathrm{ng} / \mathrm{ml}$ & $10.6(-357,221)^{\mathrm{c}}$ & $1,062(854,1,330)$ & $1,359(1,092,1,744)$ & $1,618(1,290,2,110)^{\mathrm{c}}$ \\
$\geq 20 \mathrm{ng} / \mathrm{ml}$ & $489(288,657)$ & $1,543(1,269,1,973)$ & $1,840(1,494,2,404)^{\mathrm{c}}$ & $2,098(1,685,2,781)^{\mathrm{c}}$ \\
\hline
\end{tabular}

aEstimates ( $95 \%$ bootstrap Cl) are based on a model of serum $25(\mathrm{OH}) \mathrm{D}$ as a function of vitamin D intake, race, and pubertal status and 10,000 bootstrap replicates. ${ }^{b}$ Data does not support estimating the required intake of vitamin D intake for $25(\mathrm{OH}) \mathrm{D}$ cutoff of $\geq 12 \mathrm{ng} / \mathrm{ml}$ in $50 \%$ of the study cohort. 'Cells contain results extrapolated beyond the observed quantities of daily vitamin D intake.

$25(\mathrm{OH}) \mathrm{D}$ could explain the contrast in the findings between the present study and their report.

Our findings highlight the relevance of the contributions of summertime sun exposure for maintenance of $25(\mathrm{OH})$ $\mathrm{D}$ concentrations during winter in children living in the Northeastern parts of US $(13,16)-25(\mathrm{OH}) \mathrm{D}$ concentrations of $16 \mathrm{ng} / \mathrm{ml}$ was maintained in $50 \%$ of our sample without any or negligible intake of dietary vitamin $\mathrm{D}$. The estimated daily intake of vitamin $\mathrm{D}$ required to maintain $25(\mathrm{OH}) \mathrm{D}$ concentrations at 16 and $20 \mathrm{ng} / \mathrm{ml}$ in $50 \%$ of our study cohort was 10.6 and 489 IU respectively. However, it's apparent from our data that the current IOM-set RDA of $600 \mathrm{IU} /$ day may be inadequate. Our estimated intakes of vitamin $\mathrm{D}$ needed to maintain $25(\mathrm{OH}) \mathrm{D}$ concentrations at 12,16 , and $20 \mathrm{ng} / \mathrm{ml}$ in $97.5 \%$ of our study cohort during winter were 1,137, 1,618, and 2,098 IU/day, respectively. Our findings are relevant for determining the vitamin $\mathrm{D}$ requirements of children residing in other areas of the world with comparable latitudes (above $40^{\circ} \mathrm{N}$ (e.g., Madrid, Spain) or below $40^{\circ} \mathrm{S}$ ).

Guidelines regarding dietary vitamin $\mathrm{D}$ requirements and concentrations of $25(\mathrm{OH}) \mathrm{D}$ deemed as essential for optimal skeletal health remain controversial and lack consensus at a global level. The Endocrine Society in the US has defined 25(OH)D threshold concentrations for vitamin D deficiency, insufficiency, and sufficiency as $<20,20-<30$, and $\geq 30 \mathrm{ng} / \mathrm{ml}$, respectively; and recommended a vitamin D intake of 600-1,000 IU/day in 1- to 18 -y-old children for the prevention of vitamin D deficiency and suggested a vitamin D intake of 1,000 IU/day to consistently maintain their $25(\mathrm{OH}) \mathrm{D}$ concentrations above $30 \mathrm{ng} / \mathrm{ml}(17)$. Vitamin D guidelines also vary widely in European countries (18). Nordic countries (Denmark, Finland, Iceland, Norway, and Sweden) recommend a vitamin D intake of $400 \mathrm{IU} /$ day for infants and children to achieve a target serum $25(\mathrm{OH}) \mathrm{D}$ concentration of $\geq 20 \mathrm{ng} / \mathrm{ml}$ (19). Children residing in Germany, Austria, and Switzerland have been recommended to meet a daily vitamin D intake of $800 \mathrm{IU} /$ day for maintaining a target $25(\mathrm{OH}) \mathrm{D}$ concentration of $\geq 20 \mathrm{ng} / \mathrm{ml}$ (18). Central European children are recommended a vitamin D intake of 600-1,000 IU/day to maintain a target $25(\mathrm{OH}) \mathrm{D}$ concentrations of $30-50 \mathrm{ng} / \mathrm{ml}(20)$. Given the variability in the vitamin $\mathrm{D}$ recommendations, a unifying policy guideline for addressing the prevention of vitamin $\mathrm{D}$ deficiency at global level is warranted (21).

Limitations of our study include short duration of vitamin D intervention with single instead of multiple doses, lack of information regarding travel to sunny location during the intervention period, and the presumption that the association between vitamin D intake and change in $25(\mathrm{OH}) \mathrm{D}$ concentrations is linear. Recent studies have highlighted the relevance of dietary $25(\mathrm{OH}) \mathrm{D}$ from animal foods as an undocumented food source of vitamin D (22). Vitamin D content of certain animal foods based on their potency-adjusted $25(\mathrm{OH}) \mathrm{D}$ content were higher and increased by 68 to $116 \mathrm{IU}$ (23). Incorporation of potencyadjusted $25(\mathrm{OH}) \mathrm{D}$ content in our estimates of basal dietary intake of vitamin $\mathrm{D}$ could have reduced some of the incongruence between the estimated vitamin $\mathrm{D}$ intake and serum 25(OH)D concentrations, namely, our considerably lower EAR of $10.6 \mathrm{IU} /$ day for maintaining $25(\mathrm{OH}) \mathrm{D}$ concentrations of $16 \mathrm{ng} / \mathrm{ml}$ in $50 \%$ of our study population. Representation of black children and contribution to the limited literature pertaining to the estimation of dietary vitamin $\mathrm{D}$ requirements in children are strengths of our study.

In conclusion, 25(OH)D concentration is positively associated with total vitamin $\mathrm{D}$ intake in black and white children during winter. Pubertal status is a significant predictor of 25(OH)D adjusting for vitamin D intake. Vitamin D intake required for maintaining $25(\mathrm{OH}) \mathrm{D}$ concentrations at $20 \mathrm{ng} / \mathrm{ml}$ in $97.5 \%$ of black and white children, adjusting for race and pubertal status, was threefold higher $(\approx 2,000 \mathrm{IU} /$ day $)$ than the current RDA (600 IU/day). Our findings suggest that future studies are warranted to refine the current IOM suggested $\mathrm{RDA}$ for vitamin $\mathrm{D}$ in children.

\section{METHODS}

\section{Study Design and Participants}

We conducted a secondary analysis in a subset of subjects enrolled in a randomized, double-blind, placebo-controlled trial (Clinicaltrials.gov identifier: NCT00732758) that examined the effects of supplementation with vitamin $\mathrm{D}_{3} 1,000 \mathrm{IU}$ daily for 6 mo on serum $25(\mathrm{OH}) \mathrm{D}$, parathyroid hormone, and markers of bone turnover in healthy 8- to 14 -y-old black and white children from Pittsburgh (latitude: $40.4^{\circ} \mathrm{N}$ ) and Kittanning $\left(40.8^{\circ} \mathrm{N}\right)$, Pennsylvania. Children not receiving vitamin supplements entered the trial during October through March of 2008 through 2011. Details and findings of the primary study have been reported (24). Our subjects for this study were children with baseline and 2-mo follow-up evaluations completed during October through April, a period of reduced solar ultraviolet-B (UV-B) radiation. We chose to examine the 2 mo rather than the 6-mo outcomes mainly because majority of the 6-mo follow-up visits (89\%) were completed during late spring and summer months (May through September). This strategy for subject selection eliminated the confounding effects of sun exposure on the relationship between dietary vitamin $\mathrm{D}$ and serum 25(OH)D. The clinical trial was approved by the University of Pittsburgh Institutional Review Board. Parental consent and subjects' assent were obtained prior to initiation of study procedures.

\section{Study Intervention}

Children were randomized by race to receive a vitamin $\mathrm{D}_{3} 1,000 \mathrm{IU}$ or placebo tablet once daily in a 1:1 ratio. Both the tablets were manufactured 
by Douglas Laboratories (Pittsburgh, PA), and were similar in color and appearance, and were dispensed masked in identical containers. Study medications were manufactured and supplied in two batches. The average vitamin $\mathrm{D}_{3}$ content of the vitamin $\mathrm{D}_{3}$ tablet, analyzed as described before (25), was $\approx 1129$ IU in the first batch around the mid-point of its shelf-life, and 1,140 IU in the second batch at the end of the trial.

\section{Study Measurements}

Anthropometry, skin color, dietary vitamin D and calcium, pubertal status, biochemical measurements, and compliance. Our baseline study measurements included height, weight, calculated BMI, skin color, pubertal status, and dietary intake of vitamin D and calcium intake. We assessed skin color by parent-reported sunreactive skin type $(26,27)$ and forehead melanin index using DSM II Colormeter, a hand-held dermatospectrophotometer (Cortex Technology, Hadsund, Denmark). We estimated pubertal status by physical examination $(28,29)$ and dietary intake of vitamin D and calcium using a validated food frequency questionnaire $(30,31)$. Our biochemical measurements for this analysis included serum calcium, phosphorus, albumin, and 25(OH)D collected at baseline and 2-mo follow-up. Serum $25(\mathrm{OH}) \mathrm{D}$ was assayed using liquid chromatography-tandem mass spectrometry as described before $(24,32)$. We assessed compliance by pill count at the 2-mo follow-up.

\section{Statistical Analysis}

We conducted a secondary analysis from a randomized, placebo-controlled vitamin D trial with a sample size of 157 children (24). Only children with baseline and 2-mo follow-up visits completed between October and April and no missing adherence data were included in this analysis. Therefore, the sample size for this analysis was decreased to 96 children. This sample size was not determined prior to the study.

We compared the baseline demographic, clinical, and dietary characteristics across race (black vs. white children) and treatment (vitamin D-supplemented vs. placebo) groups using two-sample $t$-tests and chi-square analyses. We used Wilcoxon Rank Sum tests to compare the medians between the respective race and treatment groups when the data were skewed. We used analysis of covariance to compare 2-mo $25(\mathrm{OH}) \mathrm{D}$, calcium, phosphorus, and albumin between the vitamin $\mathrm{D}$ and placebo groups controlling for the corresponding baseline measure. We tested within group changes of the measures using paired t-tests. We estimated the correlation between baseline $25(\mathrm{OH}) \mathrm{D}$ and changes in $25(\mathrm{OH}) \mathrm{D}$ using Pearson correlation coefficient. To estimate the required vitamin $\mathrm{D}$ intake for achieving certain concentrations of serum 25(OH)D, we used methods similar to Cashman et al. (15) by modeling the association between $25(\mathrm{OH}) \mathrm{D}$ as a function of dietary vitamin $\mathrm{D}$ (assigned group dose $\times$ adherence + dietary vitamin $\mathrm{D}$ intake at baseline) adjusting for race and Tanner stage. We tested if the association between dietary vitamin $\mathrm{D}$ and $25(\mathrm{OH}) \mathrm{D}$ was different for black and white children using an interaction term in the linear regression model. From the final regression model, we estimated the dietary intake of vitamin D that would correspond to having a percent $(50,90$, $95,97.5)$ of the population maintain serum $25(\mathrm{OH}) \mathrm{D}$ concentrations of $\geq 12, \geq 16$, and $\geq 20 \mathrm{ng} / \mathrm{ml}$. The $95 \%$ confidence intervals were calculated using bootstrap based on 10,000 replications. All tests were two sided $(\alpha=0.05)$ and analyses were conducted in SAS Enterprise Guide 6.1 (SAS Institute, Cary, NC).

\section{ACKNOWLEDGMENTS}

K.R., C.G.M., and J.Y.: conceptualized and designed the study; K.R., F.O., and M.A.H.: conducted the research and obtained the data; C.G.M. and J.Y.: performed the statistical analysis; K.R., C.G.M., S.L.G., M.F.H., and J.Y.: interpreted the data; M.F.H.: performed the 25(OH)D assay; K.R., C.G.M., J.Y., and D.C.: drafted the manuscript; All authors: critically revised the manuscript; K.R.: secured funding and supervised the study. K.R. had full access to all of the data in this study and takes responsibility for the integrity and accuracy of this work as a whole from inception to publication. The content is solely the responsibility of the authors and does not necessarily represent the official views of the National Institutes of Health.

\section{STATEMENT OF FINANCIAL SUPPORT}

This work was supported by the following grants: National Institutes of Health grants (Bethesda, MD, USA) K23HD052550 (KR), R01HL112985 (KR and CGM), K24DK062895 (SLG), P30 AG024827 (SLG), and UL1 RR024153 (University of Pittsburgh Clinical and Translational Research Center \& Pediatric PittNet); and Children's Hospital of Pittsburgh Research Advisory Committee seed grant (KR). Clinicaltrials.gov identifier: NCT00732758

Disclosures: Authors have no conflicts of interest pertaining to this manuscript.

\section{REFERENCES}

1. Heaney RP. Lessons for nutritional science from vitamin D. Am J Clin Nutr 1999;69:825-6.

2. Haddad JG Jr, Hahn TJ. Natural and synthetic sources of circulating 25-hydroxyvitamin D in man. Nature 1973;244:515-7.

3. Lawson DE, Paul AA, Black AE, Cole TJ, Mandal AR, Davie M. Relative contributions of diet and sunlight to vitamin D state in the elderly. Br Med J 1979;2:303-5.

4. Poskitt EM, Cole TJ, Lawson DE. Diet, sunlight, and 25-hydroxy vitamin D in healthy children and adults. Br Med J 1979;1:221-3.

5. Holick MF, MacLaughlin JA, Clark MB, et al. Photosynthesis of previtamin D3 in human skin and the physiologic consequences. Science 1980;210: 203-5.

6. McLaughlin M, Raggatt PR, Fairney A, Brown DJ, Lester E, Wills MR. Seasonal variations in serum 25-hydroxycholecalciferol in healthy people. Lancet 1974;1:536-8.

7. Norman AW. Sunlight, season, skin pigmentation, vitamin D, and 25-hydroxyvitamin D: integral components of the vitamin D endocrine system. Am J Clin Nutr 1998;67:1108-10.

8. Stamp TC, Round JM. Seasonal changes in human plasma levels of 25-hydroxyvitamin D. Nature 1974;247:563-5.

9. Webb AR, Kline L, Holick MF. Influence of season and latitude on the cutaneous synthesis of vitamin D3: exposure to winter sunlight in Boston and Edmonton will not promote vitamin D3 synthesis in human skin. J Clin Endocrinol Metab 1988;67:373-8.

10. Institute of Medicine. Dietary Reference Intake for calcium and vitamin D. Washington, DC: The National Academy Press; 2011.

11. Holick MF, Chen TC. Vitamin D deficiency: a worldwide problem with health consequences. Am J Clin Nutr 2008;87:1080S-6S.

12. Ng K, Scott JB, Drake BF, et al. Dose response to vitamin D supplementation in African Americans: results of a 4-arm, randomized, placebo-controlled trial. Am J Clin Nutr 2014;99:587-98.

13. Rajakumar K, de las Heras J, Chen TC, Lee S, Holick MF, Arslanian SA. Vitamin D status, adiposity, and lipids in black American and Caucasian children. J Clin Endocrinol Metab 2011;96:1560-7.

14. Yetley EA. Assessing the vitamin D status of the US population. Am J Clin Nutr 2008;88:558S-64S.

15. Cashman KD, FitzGerald AP, Viljakainen HT, et al. Estimation of the dietary requirement for vitamin $\mathrm{D}$ in healthy adolescent white girls. Am J Clin Nutr 2011;93:549-55.

16. Rajakumar K, Holick MF, Jeong K, et al. Impact of season and diet on vitamin D status of African American and Caucasian children. Clin Pediatr (Phila) 2011;50:493-502.

17. Holick MF, Binkley NC, Bischoff-Ferrari HA, et al.; Endocrine Society. Evaluation, treatment, and prevention of vitamin D deficiency: an Endocrine Society clinical practice guideline. J Clin Endocrinol Metab 2011;96:1911-30.

18. Spiro A, Buttriss JL. Vitamin D: An overview of vitamin D status and intake in Europe. Nutr Bull 2014;39:322-50.

19. Nordic Council of Ministers. Nordic Nutrition Recommendation 2012. Integrating Nutrition and Physical Activity. 5th edn. Norden: Copenhagen, Denmark, 2012. https://www.norden.org/en/theme/nordic-nutritionrecommendation/nordic-nutrition-recommendations-2012. 2015.

20. Płudowski P, Karczmarewicz E, Bayer M, et al. Practical guidelines for the supplementation of vitamin D and the treatment of deficits in Central Europe - recommended vitamin D intakes in the general population and groups at risk of vitamin D deficiency. Endokrynol Pol 2013;64:319-27.

21. Schoenmakers I, Pettifor JM, Pena-Rosas JP, et al. Prevention and consequences of vitamin D deficiency in pregnant and lactating women and children: A symposium to prioritise vitamin D on the global agenda. J 


\section{Articles | Rajakumar et al.}

Steroid Biochem Mol Biol 2015 Nov 10. pii: S0960-0760(15)30130-8. doi: 10.1016/j.jsbmb.2015.11.004 (Epub ahead of print)..

22. Heaney RP, Armas LA, French C. All-source basal vitamin D inputs are greater than previously thought and cutaneous inputs are smaller. J Nutr 2013;143:571-5.

23. Taylor CL, Patterson KY, Roseland JM, et al. Including food 25-hydroxyvitamin $\mathrm{D}$ in intake estimates may reduce the discrepancy between dietary and serum measures of vitamin D status. J Nutr 2014;144:654-9.

24. Rajakumar K, Moore CG, Yabes J, et al. Effect of vitamin D3 supplementation in black and in white children: a randomized, placebo-controlled trial. J Clin Endocrinol Metab 2015;100:3183-92.

25. Chen TC, Turner AK, Holick MF. A method for the determination of the circulating concentration of vitamin D. J Nutr Biochem 1990;1:272-6.

26. Jimbow K, Fitzpatrick TB, Wick MM. Biochemistry and physiology of melanin pigmentation. In: Goldsmith LA, ed. Phyisology, Biochemistry, and Molecular Biology of the Skin. New York, NY: Oxford University Press; 1991:893-909.
27. Pathak M, Jimbow K, Szabo G, Fitzpatrick TB. Sunlight and melanin pigmentation. In: Smith K, ed. Photochemical and Photobiological Reviews. New York, NY: Plenum Press; 1976:211-39.

28. Marshall WA, Tanner JM. Variations in pattern of pubertal changes in girls. Arch Dis Child 1969;44:291-303.

29. Marshall WA, Tanner JM. Variations in the pattern of pubertal changes in boys. Arch Dis Child 1970;45:13-23.

30. Rockett HR, Breitenbach M, Frazier AL, et al. Validation of a youth/adolescent food frequency questionnaire. Prev Med 1997;26:808-16.

31. Rockett HR, Wolf AM, Colditz GA. Development and reproducibility of a food frequency questionnaire to assess diets of older children and adolescents. J Am Diet Assoc 1995;95:336-40.

32. Holick MF, Siris ES, Binkley N, et al. Prevalence of Vitamin D inadequacy among postmenopausal North American women receiving osteoporosis therapy. J Clin Endocrinol Metab 2005;90:3215-24. 